\title{
Brand Preference for Mobile Phone Operator Services in the Cape Coast Metropolis
}

\author{
Anthony Dadzie \\ Territory Manager, Millicom Ghana Limited \\ Cape Coast, Ghana \\ Tel: 233-277-455-883Ｅ-mail: Anthony.Dadzie@tigo.com.gh \\ Francis Boachie-Mensah (Corresponding author) \\ School of Business, University of Cape Coast \\ University Post Office, Cape Coast, Ghana \\ Tel: 233-332-137-870 E-mail: fbmens2002@yahoo.co.uk
}

Received: March 23, 2011

doi:10.5539/ijbm.v6n11p190

\author{
Accepted: June 1, $2011 \quad$ Published: November 1, 2011 \\ URL: http://dx.doi.org/10.5539/ijbm.v6n11p190
}

\begin{abstract}
Branding is increasingly being used as a strategy for managing markets in developed countries while developing countries still lag behind. The objective of this study was to assess the level of brand awareness and factors underlying brand preference of mobile phone service brands in Cape Coast market in Ghana. A total of 100 respondents who included individual consumers were selected using accidental simple sampling technique. Primary data was collected using structured interview schedules developed for each category of consumers. The findings of the study showed that most of the respondent consumers were aware of mobile phone operator brands despite having come across few operator service advertisements. Young males, mainly students in the tertiary institutions, single and of Christian affiliations, dominated the market. Four factors were identified as key determinants of mobile phone operator service choice, namely promotion, price and availability of product, attractive packaging and product quality. There is need for mobile phone operators to incorporate these findings in the formulation of responsive marketing strategies.
\end{abstract}

Keywords: Brand preference, Consumer behaviour, consumer personality, Consumer preference, Consumerism, Corporate branding, Mobile phone usage, Product quality

\section{Introduction}

The Ghanaian mobile sector was selected as an object of analysis because since launching the first cellular mobile network in sub-Saharan Africa in 1992, Ghana has become one of the continent's most vibrant mobile markets with four competing operators. Zain and Glo Mobile had entered and acquired license to inch up the competition further. The Ghanaian regulator the National Communications Authority (NCA) has also granted one WiMAX license to the ISP Internet Ghana.

\subsection{Structural change in the Ghanaian industry}

Overå (2005), studying cell phones on informal traders' business practices in Ghana, concluded that telecommunications has changed their mode of operation by reducing both transportation and transaction costs. The study observed that traders offered more efficient communication create a higher profit potential than others without them. It further argued that adoption of new technology enhances trust building in trade networks, thus facilitating a higher number of transactions in an uncertain economic environment. According to World Celluar Reports, the first cellular phone service in Ghana was initiated by Mobitel in 1992. In that year alone, 19,000 Ghanaians owned mobile phones. In 1998 the number of mobile phone users in the country increased to 43,000 and by the middle of 1999 the number increased to 68,000 . This was doubled to 132,000 by end 2000 with mobile operators, Spacefon, Onetouch, Mobitel and Celltel using the GSM, (E)TACS and AMPS standards respectively (http://www.bizlib.com/Communications-and-Technology-Africa-Middle-East).

According to Online Resource Informa (2008), the current license framework only became effective in 2004 when mobile operators for the first time were issued long-term licenses. Hitherto, operators were granted yearly authorizations to use a specific spectrum. Millicom introduced mobile services in Ghana in 1992, operating a TACS network. The operator then launched GSM in 2002. Celltel, which later became Kasapa, entered the market in 1995 with an AMPS network, while Scancom and One Touch followed in 1996 and 2000 respectively. MTN, which entered Ghana in 2006 through its \$5.5bn takeover of Investcom, which owned Scancom, is Ghana's market leader. Millicom's Tigo is in second place, Vodafone's One Touch is third and Hutchison's Kasapa fourth. At the end of 2006, Ghana had 4.9 million subscriptions, by June 2008 that figured had nearly doubled to 9.4 million. Mobile subscriptions in Ghana increased by 59 per cent year-on-year in Q108. With total 
African subscriptions growing by 40 per cent over the same period (http://www.informa.com/subjects/telecoms-and-media)

Informa further indicates that Ghana is Africa's ninth largest mobile market and West Africa's second largest by subscription count after Nigeria. Informa also forecasts that the 10 million subscriptions mark will be passed before the year is out. The country will by then have six mobile networks as both Glo Mobile and Zain are expected to launch during Q408. Tigo recorded the highest year-on-year growth, 84 per cent, in Q108, taking market share from Scancom, which had 52 per cent of the country's subscriptions in Q108. Though Scancom had the highest Average Revenue Per User (ARPU); \$14 in Q208, with 97 per cent of spending on voice services, Vodafone's OneTouch had an ARPU of $\$ 9$ for the same period which compares favorably with Kasapa's $\$ 8$ and Tigo's $\$ 7.5$.

Africa, particularly sub-Saharan Africa, is under scrutiny now. Despite increased growth in recent years, mobile penetration remains relatively low and countries across the region are seen as an attractive option in the overseas expansion plans of ambitious carriers. Vodafone plans to launch a $3 \mathrm{G}$ network in Ghana through OneTouch, which might enable it to establish new sources of revenue from data services. The sale of 70 per cent of Ghana Telecom to a strategic investor Vodafone was not a surprising as the process had begun in 2006. However, Vodafone was not among the initial bidders mentioned. France Telecom was reported to be the winner in November 2006. However, in February 2008, it was reported that the government had suspended the sale of shares in Ghana Telecom. France Telecom's $\$ 520 \mathrm{~m}$ offer had been rejected because the government put a higher price on the company's assets. Vodafone was announced as the winner on 3rd July 2008. The UK group closed the deal in August acquiring a 70 per cent stake from the Ghanaian government for $\$ 900 \mathrm{~m}$. The deal was struck on a debt-free, cash-free basis, implying a total enterprise value for Ghana Telecom of about $\$ 1.3 \mathrm{bn}$. The government will retain 30 per cent of the company.

Vodafone's entry into Ghana fits into its strategy of expanding aggressively into emerging markets to offset slowing growth in mature markets. It gives the UK firm access to one of the remaining attractive markets in the region. The challenges will mainly lie in Ghana Telecom's fixed-line assets, and Vodafone will have to deal with heavy debts and reducing the number of staff. The move was a final feather in the cap for former Vodafone chief executive officer Arun Sarin who stepped down at the end of July 2008. Sarin observes that "Ghana is one of the most attractive markets in Africa with mobile subscribers growing at more than 55 per cent per annum. Our extensive operating experience together with our portfolio of products and services position us well to deliver a superior mobile experience to Ghanaian customers and significantly improve financial performance. Vodafone is aiming for Ghana Telecom to ultimately raise its mobile market share to about 25 per cent, reversing recent underperformance." Sarin adds that over the next five years Ghana Telecom is to invest over $\$ 500 \mathrm{~m}$ in its operations and network, restoring and expanding network coverage and completing and integrating the fibre backbone as well as introducing initiatives such as M-PESA and ultra-low cost handsets.

Back in Q108 Hutchison announced that it had sold Kasapa, Ghana's fourth mobile (CDMA) operator, to EGH International Limited for $\mathrm{HK} \$ 584 \mathrm{~m}(\$ 74 \mathrm{~m})$. The deal is hanging in the balance, however, dependent on regulatory approval. And there is an ongoing court case between Kasapa and former local shareholders. The court case was not mentioned by Hutchison as an obstacle to the transaction and there was no information on EGH's activities or its country of origin. Rumours link EGH to Sudanese operator, Sudatel, but the Sudanese company has so far not mentioned any investment in Ghana (http://www.informa.com/subjects/telecoms_and_media).

Informa Telecoms \& Media forecasts that mobile subscriptions in Ghana will grow by 47 per cent between 2007 and 2011. The country's penetration rate will then reach 41 per cent. In comparison, Africa as a whole will grow by 48 per cent by 2011 to reach 385 million subscriptions and a penetration rate of 38 per cent. Recent oil discoveries in Ghana could boost the disposable incomes of the country's users over the medium or long term. The population of Ghana is not poor in comparison with some of their West African neighbors; however, nearly 30 per cent of citizens live below the poverty line making mobile communications a luxury that some can ill afford. Competition is set to increase, potentially driving ARPUs down further as operators compete on price and tap into lower-income groups for growth. With increasing competition and rapidly falling ARPU in Ghana, industry players valuation is starting to look high. West Africa might look like a promising investment opportunity to Western Carriers and maybe Vodafone can leverage its scale to help it compete. However, emerging markets pose a host of challenges and pitfalls that make some carriers, such as Hutch, decide they are better off getting out of Africa.

\subsection{Global developments affecting the mobile sector}

During the past two decades it has become clear that brands are among a company's most important assets (Nijssen, 1999). Davis (2002) expresses that the most powerful organisations in the world have all had success related to their strong brands. A contrast can be drawn between firms in developed countries and those in the developing world. Whereas, the earlier predominantly operate under the societal marketing concept, whose central principles are satisfying customer needs and wants using environmentally friendly methods, the latter function under either the product or production concepts. Therefore firms in these countries mostly produce goods and services usually without incorporating consumer needs, wants and aspirations. The need for mobile phone operators to establish their brand positioning and brand preference is critical if they are to successfully compete in the current unpredictable and competitive business markets. Successful brands are known to create 
and articulate the sustainable differential advantage of the underlying product (Ward, 2004). Organizations brand their offerings in order to distinguish their product or service from competition and clutter. Since the inception of the concept of branding, building and maintaining strong brands have been the distinctive feature of all successful companies. Building the right relationship between the brand and its customers creates successful brands. Brands with the greatest equity are the most profitable because their customers are generally more loyal and willing to pay higher prices for the product, and have a closer relationship with the brand (VNU Marketing Information Services, 2003). Branding obviously has advantages for organisations, since it helps to differentiate the product from the competitor's product. Economies of scale and scope are attributed to branding, and a brand with high sales will generate production economies. Studies in some sectors have shown that customers who are 'most loyal' to a brand will pay as much as a $20 \%$ premium before they will switch to a different company's product. A clear understanding of the factors affecting brand preference is also critical to ensure that branding efforts by the company are synchronized with the needs of local consumers of dairy products. Extant literature shows that consumers are influenced by various factors when choosing among alternative brands. These factors include relative advantage, perceived risk, complexity, compatibility, observability, image, price and trialability (Rogers, 1995; Tornatzky and Klein, 1982; Mason, 1990; Charlotte, 1999).

In a study of factors that affect brand decision in the mobile phone industry in Asia, Lui (2002) explained that the choice of cellular phone is characterized by two distinct attributes to brands: attitudes towards the choice of mobile phone on one hand and attitude towards the choice of network operator on the other hand. While price and regularity of service were found to dominate choices between network providers, new technology features such as memory capacity and SMS options influenced that of mobile phone brands. The trend, the study concluded, is actually not towards smaller phones but phones with better capability and larger screens. The adoption of mobile phones and services has been exceptionally rapid in many parts of the world. Riquleme (2001) conducted an experiment with 94 consumers to identify the amount of self-knowledge consumers have when choosing between mobile phone brands. The study identified six key attributes; telephone features, connection fees, access cost, mobile-to-mobile phone rates, call rates and free calls. He concluded that consumers with prior experience about products can predict their choices relatively well but consumers tend to overestimate the importance of features such as call rate and free calls and underestimate the importance of a monthly access fee, mobile-to-mobile phone rate and connection fee. With many regional markets now close to the saturation point and little in the way of differentiation in underlying infrastructure, consumers are being influenced in their choice of provider by brands that appeal to their particular demographic; social and family reference groups, income levels and educational backgrounds (http://www.gsmworld.com).

Although mobile phones have become a fundamental part of personal communication across the globe in recent years, consumer research has devoted little specific attention to motives and choice underlying the mobile phone and operator buying decision process. Karjaluoto et al (2005) explain that there are numerous complex factors that need to be taken into account when exploring mobile phone market in general and individual consumer's motive and decision making in particular. Moreover, it is important to distinguish between buying behaviour referring to the choice of mobile phones and operator brands. Industry players in the mobile markets frequently conduct market research as part of their corporate strategy. However, their findings usually remain behind company walls. Brand preference, purchase motives and usage patterns of mobile service in Ghana are relatively unexamined in genre academic literature thus necessitating this study. This study sought to explore the dynamics of brand preference in the mobile phone sector in Ghana with respect to operator choice by consumers in the Cape Coast Metropolis. The findings of the study would provide a platform for a more detailed research in the area of mobile brands operating in Ghana. Finally, it would contribute to existing literature in this area, which would subsequently inform industry players in formulating marketing strategies.

\section{Literature Review}

\subsection{Brand and branding defined}

It is widely acknowledged amongst both practitioners and academics that branding has become a tool of strategic importance. Various definitions of branding appear in literature. Kotler (1991) defines a brand as "a name, term, sign, symbol, or design, or combination of them which is intended to identify the goods and services of one seller or group of sellers and to differentiate them from those of competitors". However, Bedbury (2000) asserts that a brand is not a product but rather the sum total of everything a company does - the good, the bad and even the off strategy - that creates a large context or an identity in the consumer's mind. Further, he explains that a brand is a promise and a mark of trust. A primary function of the brand is to provide convenience and clarity in decision making by providing a guarantee of performance and communicating a set of expectations thereby offering certainty and facilitating the buying process. On the emotional side, the function of a brand is to evoke a set of associations and furthermore symbolize the consumer's persona through brand imagery. However, this and other definitions of a brand fail to capture the essence of what branding involves or achieves (Marketing in a Global Economy Proceedings, 2000). In order to be successful, images and symbols must relate to and indeed exploit the needs, values and lifestyles of consumers in such a way that the meanings involved give added values, and differentiate the brand from other brands (Broadbent and Cooper, 1987). In its totality, a brand can be described as a "trademark that communicates a promise (Phillips, 1998). This promise involves a set of symbolic and functional attributes that the market place associates with the brand. Symbolic attributes are those that fulfil internally generated needs for self-enhancement, role position, group membership or ego identification (Park et 
al., 1986) whereas functional brand attributes solve an externally generated consumption related problem. Baker (1991) defines brand preference as the consumer's inclination to select or choose a specific brand of product in preference to any other having a similar composition and cost or performance characteristics. The evaluation of brand by a person who is a current user of that brand is likely to be different from non-users and even past users. This is because product modification occurs every now and then especially where a number of brands available in a product category are numerous (Marfo-Yiadom, 2000).

\subsection{Factors affecting brand preference}

Mobile phone markets are one of the most turbulent market environments today due to increased competition and change (Karjaluoto et al, 2005). Thus, it is of growing concern to look at consumer buying decision process and cast light on the factors that finally determine consumer choices between different mobile phone and operator brands. Karjaluoto et al (2005) explain numerous complex factors that need to be taken into account when exploring mobile phone buying decision process, including both macro- and micro-economic conditions that affect the evolution of mobile phone market in general and individual consumer's motives and decision making in particular. Moreover, it is important to distinguish between buying behaviour referring to the choice between different mobile phone models and brands aspects referring to reasons that influence choice. User demography, sources of information search, brand attributes, service usage and satisfaction levels among users were the focus of the study.

\subsubsection{Demography and operator choice}

Lachance and Choquette-Bernier (2004) conducted a survey of young Finnish people aged 16-20 and found that mobile phone choice and usage is consistent with respondents' general consumption styles. The research showed that addictive use was common among females and was related to trendy and impulsive consumption styles. Young males however were found to be more trend-consciousness and technology-savvy. These attributes were then linked to impulsive consumption from which he concluded that genders are becoming more alike in mobile service choice. Similarly, Fitzsimons (2002) explains that consumer choice can also be approached from the perspective of conscious and non-conscious choice. In addition, he submits that quite many choice situations occur outside of conscious awareness and with limited information search and can be stated that many choices have both conscious and non-conscious motives. Available information on demography of European mobile users shows that the 18-24 year groups are the most active user group (http://www.itfacts.biz). It further indicates that some $66 \%$ of Americans between the ages of 30-49 use SMS with a whopping $65 \%$ of its unemployed population having used mobile phones in the past. Karjaluoto et al (2005) argues that demographic factors have an influence on the evaluations of different attributes related to mobile phone choice. Specifically, maintaining that gender and social class will influence these evaluations since men, belonging to higher social class, are more technologically enthusiasts than their opposite sex.

\subsubsection{Consumer choice behaviour and brand preference}

Consumer choice behaviour has been studied using the five-step process (need-information search-evaluation of alternatives-purchase-post-purchase evaluation) of problem solving paradigm or through the progression of consumer choice from a product class to brand choice (Dorsch et al., 2000). Discrete choice models (Chintagunta, 1999; Bockenholt and Dillon, 2000) or neural networks to model selection decisions (Papatla et al., 2002) have also been used in brand choice research. Brand preference is the measure of brand loyalty in which a consumer will choose a particular brand in the presence of competing brands, but will accept substitutes if that brand is not available. Baker (1991), however, considers brand preference as the inclination to select or choose a specific brand of product in preference to any other having a similar composition and cost or preference characteristics. Products compete in a complex environment of mass market with consumers exposed to hundreds of advertisements on an average day. Proper selection of brand helps products make a distinct and favorable impression on the consumer. For this, among other reasons, industry players must understand consumer needs and their target market in order to fashion communication objectives that specifically meet the expectations of the target group. Consumption activities not only encompass the economic capacity to buy goods and services but also involve skills, attitudes and knowledge associated with a rational approach to consumption. Kotler (2006) defines consumer behaviour as the study of how individuals, groups and organizations select, buy, use and dispose of goods, services, ideas or experiences to satisfy their needs and wants. According to Kotler, studying consumers provides clues for improving or introducing products or services, setting prices, devising channels, crafting messages and developing other marketing activities. Thus, understanding consumer choice and usage in the mobile markets will have both theoretical and management implications for marketing planning and make industry players market-oriented rather than product or service-oriented.

Although the study is not on consumerism and consumer competence, but rather on brand preference, yet a brief highlight on the former is undertaken in a bid to appreciate consumer behavior in the mobile market. Kotler et al (1988) define consumerism as an organized movement of consumers whose aim is to improve the rights and powers of buyers in relation to sellers. Based on the criteria used by Lachance (2004), consumer competence could be defined as a multi-dimensional concept composed of cognitive, affective and behavioral aspects related to well-advised, prudent and responsible consumer activities. Asher (1998) argues that while much attention has been devoted to issues of consumer protection in many countries, there are fundamental differences in the consumer protection philosophies between developed and developing countries of the world. In the developed world, consumers are deluged with alternatives and governments have much greater faith in the market's ability 
to deliver benefits to consumers, increasingly relying on market mechanisms rather than government regulations. However, the situation is different in developing and underdeveloped economies where consumerism is in early stages of growth and consumers rely more on government intervention for protection. Under these circumstances, there is the need for more studies on regulations relating to consumer protection issues in developing countries. Studies undertaken in Saudi Arabia focused on consumer protection agencies and their operations, the findings of which show that Saudi consumers were averse to approaching consumer protection agencies for complaints even when they are dissatisfied with the products and services (Al-Qahtani, 1991; Al-Hamad, 1993). Bhuian et al's (2001) study found that in Saudi Arabia young adults who had a business education background were more favorably disposed towards marketing and consumerism issues than those who had a non-business background.

\subsubsection{Sources of information for mobile operator brands}

In the light of the classical problem solving buying behavior, consumers engage in information search before making the actual choice. Consumer decision-making process is usually guided by already formed preferences for a particular alternative. This means that consumers are likely to make the choice between alternatives based on limited information search activity and without detailed evaluation of the other alternatives (Chernev, 2003). In close relation to information search, evaluation of alternatives has also gained a momentum in recent research (Laroche, Kim and Matsui, 2003). Laroche et al's (2003) study of five heuristics (conjunctive, disjunctive, lexicographic, linear addictive and geometric compensatory) in the consideration set found that conjunctive heuristics is the most often used decision model in the consideration set formation for two product classes in the study (beer brands and fast food outlets). The researchers consider conjunctive heuristics to occur when a consumer selects a brand only if it meets acceptable standards, that is, the so-called cutoff point on each key attribute a consumer regards as important. As such, a consumer would eliminate a brand that does not fulfill the standards on one or two of the most important attributes, even if it is positive on all other attributes.

It is widely accepted that the traditional problem-solving approach involving rational decision making to the study of consumer choice may not be suitable for all situations or is at least incomplete to understand choice behaviour. Limited information search and evaluation of alternatives led to a situation in which consumer choice is also driven by hedonic considerations (Dhar, 2000). Generally, however, a common distinction to be made is that while utilitarian goods usually are primarily instrumental and functional, hedonic goods provide fun, pleasure and excitement. Batra, and Ahtola, (1990), in "Measuring the hedonic and utilitarian sources of consumer attitude," noted that many choices have both utilitarian and hedonic features and, thus, it can be proposed that the choice between mobile phones and operator brands has both utilitarian (e.g. communication, time planning) and hedonic (e.g., games, camera) features. The mobile phone is a type of information good whose value is dependent on the information embedded in it or facilitated by it and depends on a network to realize its full value. It shares some characteristics of an experience good in that some of its features may be sampled ahead of time, but the device's value becomes clear once the consumer has begun to use it. The fact that the mobile phone gives access to a networked service adds another layer of consumer uncertainty. Lachance (2004) asserts that young people seem to show many deficiencies in terms of consumer competence in the mobile services and that very little is known about what information sources would help to develop their competence in this area. Youth is a time for many new and important consumer experiences (buying furniture or a car, using credit cards, etc.) and for learning consumer preferences, attitudes and behaviors, many of which will persist during the rest of their adult life. Wilska (2003) further argues that the younger the consumer, the more hedonistic features he or she tends to value in mobile phones. Mobile phone choice and use, he concludes, was related to prior consumption styles.

\subsubsection{Brand attributes of mobile operators}

Keller (1993) explains that attributes of a brand are those descriptive features that characterize a product or service. In effect, what a consumer thinks the product or service is or has and what is involved with its purchase or consumption. Attributes can be distinguished according to how directly they relate to product or service performance. Product-related attributes constitute the ingredients necessary for performing the product or service function sought by consumers. Hence, they relate to a product's physical composition or a service's requirements and vary by product or service category. Non-product-related attributes are external aspects of the product or service that relate to its purchase or consumption. The four main types of non-product-related attributes are price information, packaging or product appearance information, user imagery (i.e. what type of person uses the product or service), and usage imagery (i.e. where and in what types of situations the product or service is used (ibid). Keller (1993) further explains that the price of the product or service is considered a non-product-related attribute because it represents a necessary step in the purchase process but typically does not relate directly to the product performance or service function. Blattberg (1989) rather considers price to be a particularly important attribute association because consumers often have strong beliefs about the price and value of a brand and may organize their product category knowledge in terms of the price tiers of different brands. Similarly, packaging is considered as part of the purchase and consumption process but, in most cases, it does not directly relate to the necessary ingredients for product performance.

User and usage imagery attributes can be formed directly from a consumer's own experiences and contact with brand users or indirectly through the depiction of the target market as communicated in brand advertising or by some other source of information (e.g. word of mouth). Plummer (1985) asserts that one component of brand image is the personality or character of the brand itself. The research demonstrated that brands could be 
characterized by personality descriptors such as "youthful," "colorful," and "gentle". These types of associations seem to arise most often as a result of inferences about the underlying user or usage situation. Brand personality attributes may also reflect emotions or feelings evoked by the brand. Benefits are the personal value consumers attach to the product or service attributes and refers to what consumers think the product or service can do for them. Park (1986), however, classifies benefits into three categories, according to the underlying motivations to which they relate: (1) functional benefits (2) experiential benefits and (3) symbolic benefits. Functional benefits are the intrinsic advantages of product or service consumption and usually correspond to the product-related attributes. These benefits often are linked to basic motivations such as physiological and safety needs and involves a desire for problem removal or avoidance (Keller, 1993). Experiential benefits relate to what it feels like to use the product or service and usually correspond to the product-related attributes. These benefits satisfy experiential needs such as sensory pleasure, variety and cognitive stimulation. Symbolic benefits are the more extrinsic advantages of product or service consumption. They usually correspond to nonproduct-related attributes and relate to underlying needs for social approval or personal expression and outer directed self-esteem. Hence, consumers may value the prestige, exclusivity or fashion ability of a brand because of how it relates to their self-concept (Solomon, 1983). Symbolic benefits should be especially relevant for socially visible, "badge" products

\subsection{Brand equity}

Keller (1993) explains that building customer-based brand equity requires the creation of a familiar brand that has favorable, strong and unique brand associations. This can be done both through the initial choice of the brand identities, such as the brand name, logo, or symbol, and through the integration of the brand identities into the supporting marketing program. He concludes, these alternatives are chosen to help enhance brand awareness or facilitate the linkage of brand associations underpinning the psychological principles that are useful in understanding how the choice of a name affects brand recall and recognition processes. Further, Keller (1993) suggests that brand names should be simple, familiar, and distinctive, along the following lines to enhance the likelihood of successful processing at encoding. The brand name should be easy to comprehend, pronounce and spell. What market researchers commonly refer to as the "flicker perception" of brand names (i.e. how quickly a brand name can be perceived and understood when exposed only for an instant) to assess consumer learning of candidate brand names. Again, the use of a familiar word should be advantageous because much information is present in memory to which the name relates. As such, a distinctive word is often sought to attract attention and reduce confusion among competing brands. These different choice criteria for a brand name are not necessarily mutually compatible and it may be difficult to choose names that are simple, familiar and distinctive. Srull's, (1982) findings suggest that choosing a familiar word to represent a well-known concept or some other common object or property as a brand name may facilitate brand recall but choosing a more unusual or distinctive word may facilitate brand recognition. Ideally, the brand name can be effectively supported through marketing communications and a distinctive slogan that ties together the brand name and its positioning.

\subsection{Operator services and usage}

The shift from $2 \mathrm{G}$ to $3 \mathrm{G}$ technology is expected to change the way people use their mobile phones, and the services operators offer. The rise of the $3 \mathrm{G}$ network and its consumer acceptance is said to be one of the toughest marketing challenges in recent history (Benady, 2002). He states that the success of $3 \mathrm{G}$ depends primarily on how the real benefits of the technology are marketed to consumers, on one hand, and on pricing policy of the services, on the other. He explains that the hype around $3 \mathrm{G}$ is not a revolution in mobile phone markets, but rather an evolution where consumers are able to do the same things they could with $2 \mathrm{G}$ and $2.5 \mathrm{G}$ only better and faster in terms of download times. Sehovic (2004), however, argues that consumer shift from 2G to 3G means that, in order to be able to use the services offered by the faster network, consumers need to acquire new mobile handsets equipped with Internet access and new features such as possibility to receive and send multimedia messages. Although recent news indicates a strong demand for new mobile phones equipped with colour displays and built-in camera, there still is plenty of skepticism in the media, as well as in the market itself, towards the technological development. Jones (2002) conducted a study on 470 early adopters on behalf of Tarifica and shows that $3 \mathrm{G}$ has the potential to be successful if it is marketed to the right audience with focus on real consumer needs. In a nutshell, the real benefit of $3 \mathrm{G}$ mobile devices relates to faster, cheaper and easier access to the Internet and most importantly not bound to place. Hansen (2003) argues that communication is not the only need mobile phones fulfil, and that beyond voice three main trends are shaping the so-called mobile culture today: (1) communication services such as voice, text and pictures, (2) wireless Internet services such as browsing, corporate access and e-mail, and (3) different media services such as motion pictures, games and music. For example, telecommunications companies promote new services such as multimedia messaging service (MMS) as a new way of enhancing one-to-one and one-to-many communicating. According to a study conducted in the UK, close to 40 percent of the youth market uses MMS (Enpocket, 2004). Similar literature has established a direct link between handset manufacturers and service providers within the overall mobile value chain (Sugai, 2007; Kim and Yoon, 2004; McBride 2003). The researchers explored factors influencing the adoption and usage of content and service sites via the mobile handset as well as the acceptance of mobile advertisement. Nevertheless, the industry is considered a relatively unexamined genre in academic circles. 


\subsection{Consumer satisfaction in mobile network}

Recently, there has been considerable controversy about whether there is a link between customer satisfaction and retention. The crux of the matter is for industry players to understand how customers' assessments of services influence their subsequent behavior. Equally vital is for managers to acquire a better understanding of the relationship between satisfaction and the duration of provider-customer relationship. This would enable managers identify specific actions that can increase retention and profitability in the long run. Bolton (1998) suggests that service organizations should be proactive and learn from customers before they defect by understanding their current satisfaction levels. Managers and researchers may have underestimated the importance of the link between customer satisfaction and retention because the relationship between satisfaction and duration times is very complex and difficult to detect without advanced statistical techniques. Consequently, he proposes that, instead of "learning from defections", service organizations should be proactive and learn from customers before they defect by understanding their current satisfaction levels. Relationship marketing efforts have typically emphasized customization of products to individual customers, augmentation of core services, pricing, and other so-called defensive marketing strategies that are purported to encourage satisfaction, loyalty, and the duration of the provider-customer relationship. However, according to Maktoob research (2008), a basic definitional inconsistency exists by the debate whether satisfaction is a process or an outcome. He argues that while most definitions favour the notion of consumer satisfaction as a response to an evaluation process, there is an overriding theme of consumer satisfaction as a summary concept. It embodies a fulfillment response; affective response, overall evaluation, psychological state, a global evaluative judgment, summary attributes phenomenon or an evaluative response (http://maktoob-research.com/).

\section{Methodology}

Quantitative survey research design was employed in the study. The primary data for the study was obtained from a field survey, which involved the use of self-administered questionnaires to the mobile customers of the Cape Coast Metropolis in Ghana. The target population comprised of students and youth groups, market women, families, friends, and corporate firms using mobile phones and mobile services in the Central Region of Ghana. Since mobile services usage is a mass-market product, the critical mass of the population in Cape Coast was interviewed. This was to ascertain the mobile users' views on their intentions to opt for one mobile operator's brand over another. The accidental sampling method was used because the target population could not be found at one place. Any mobile user who happened to be in the study area was selected.

Questionnaires were used as the main research instrument. The questionnaires consisted of both open- and closeended questions. One hundred questionnaires were distributed, and they were administered using the social survey approach. First, brand attributes considered for the study were determined from focus group discussions. The factors involved were characteristics of consumers of mobile services which were considered most important by consumers in selecting their operator brand. Eight attributes were involved: Network Coverage, Customer Service, Access to Recharge Credit Tariffs, Brand Communication, Value-Added Services, Brand Image, Activation \& Operating Cost were selected for the study. A pilot sample questionnaire was constructed and administered on a group of mobile users to determine their ability to complete the instrument. A final questionnaire was designed and administered to some 100 mobile users in the Central Business District, University of Cape Coast campus and Cape Coast Polytechnic campus. The questionnaire used consisted of four sections. Demographic characteristics and sources of information by mobile operators constituted sections A and $\mathrm{B}$ respectively. In section $\mathrm{C}$ respondents were asked to rank brand attributes of mobile operators. Section D was used to determine respondents' familiarity and usage of operator services. Data collection was done in February 2009. The data collected was processed electronically using the Statistical Package for Social Science (SPSS 15.0) to analyze the data collected. This made the analysis faster and convenient. The data was edited, coded and entered into the computer for analysis. Omissions and errors were checked and corrections made where necessary. In addition, the data was presented using charts and tables which are simple and easy to understand.

\section{Discussion of Findings}

\subsection{Demographic characteristics of operator service usage in Cape Coast Metropolis}

The study showed that $60 \%$ of respondents were of the 21-30 year age group with the lowest been the 41-50 year group. Some $87 \%$ of the respondents were under 40 years. This distribution is relevant as it indicates that the critical mass of young mobile phone users in the Cape Coast metropolis. This is also consistent with the increasing urbanization to Cape Coast by the reproductive age leading to an 18\% growth from 2000 (Population and Housing Census, 2000). However, this varies slightly with Western demographic characteristics, which indicate phone and operator service adoption in a lower age group of between 18-24 years (Lachance and Choquette-Bernier (2004; www.itfacts.biz). Table 1 shows the demographic characteristics of the respondents.

\section{Insert Table 1 - Here}

Males dominated females in the survey by 71 to $29 \%$, with over $80 \%$ of the respondents having post-secondary education. Additionally, $99 \%$ had education beyond primary school, and this facilitated the administration of the questionnaire. This is consistent with, but above, the $75.3 \%$ adult literacy rate recorded for the regional capital in the last census (Population and Housing Census, 2000).

In the study, Blue-Collar was used to indicate employment in the clerical and supervisory capacity and White-Collar management capacity. Although students constituted the majority of respondents in the study, other 
workers such as research assistants, messengers, taxi drivers among others, depicted the diverse nature of respondents' income status. Cape Coast is endowed with educational institutions, Ministries, Departments and Agencies (MDA's); thus over 89 per cent of our respondents were from these employment backgrounds.

Although religious affiliation and nationality were not featured in the Table 1, it is important to mention that Christians and Ghanaians respectively attained highest scoring on the aforementioned demographic characteristics. This was in line with the 2000 Population and Housing Census that indicated Christians form majority of city's religion while some $97 \%$ of Ghanaians forms the Nationality mix of the metropolis.

\subsection{Sources of information for operator brand choice and services}

The study revealed that respondents, in choosing operator brand, mostly used commercial sources such as electronic and print (71\%) media compared to social cues such as word-of-mouth (23\%). (See Figure 1]) Also, television was the most preferred electronic source as was newspaper and friends for print and word-of- mouth respectively. The evidence is in line with the view of Marfo-Yiadom (2000), who explains that social cues occur when a consumer shares information about a brand with families, friends, co-workers among others. This is an interpersonal source with no affiliation to the seller or manufacturer of the brand. The commercial cues on the other hand consist of the various activities (advertisement, personal selling sales promotion and other Integrated Marketing Communication tools) that the seller/producer attempts to communicate the brand to the consumer. This stimulus engendered to generate output, which may include purchase, attitude, intention or brand comprehension. Purchase is the act of buying a product; however intention is the consumer's forecast of the brand choice and potential future purchase. Attitude constitutes a consumer's evaluation of a brand's potential to satisfy motive while brand comprehension comprises of the store of brand knowledge a consumer possesses at any point in time (Engel et al, 1973).

\section{Insert Figure 1 - Here}

The study further tested the most preferred information source used by respondents in adopting operator services. Seventy percent indicated their use of commercial cues to adopt mobile operator services compared to social cues (Figure 2). Additionally, newspapers, friends and TV were established as the most preferred channels for adopting operator services respectively in the print, word-of mouth and electronic media (Figures 3,4 and 5). These have significant implications in the marketing and communication of operator brands and services.

\section{Insert Figure 2 - Here}

\section{Insert Figure 3, Figure 4 \& Figure 5 - Here}

\subsection{Attributes of mobile operator brands}

The study revealed that respondents valued some attributes more than others in choosing their mobile operators (Table 2). Respondents ranked Network Coverage (19\%) highest in the order of importance above Customer Service $(14 \%)$, Access to recharge credit $(14 \%)$, Tariff $(12 \%)$, Value-Added Services $(12 \%)$, Brand Image $(10 \%)$, Brand Communication (10\%) and Activation Cost respectively (10\%) (Table 2). The result is consistent with the view of Solomon (1983), who considers conjunctive heuristics to occur when a consumer selects a brand only if it meets acceptable standards. He further asserts that each key attribute a consumer regards as important would be maintained and those that do not make the cutoff would be eliminated. In summary, a consumer devalues a brand that does not fulfill a standard on one or two of the most important attributes, even if it is positive on all other attributes.

Network coverage is the most basic attribute for a mobile operator, without which other attributes cannot be assessed. It relates to the functional or product-related attribute of a brand. This consists of the product's physical composition or a service's requirements and varies by product or service category (Keller, 1993). Network coverage is of upmost importance because the operator must be able to locate a moving phone anywhere in the world in order to deliver the experiential and symbolic attributes of the brand.

\section{Insert Table 2 - Here}

Brand image defined as perceptions about a brand as reflected by the brand associations held in consumer memory was of little significance to the respondents in the Cape Coast metropolis thereby ranking it among least important (Table 2). Symbolic benefits are the extrinsic advantages of product or service consumption and correspond to the nonproduct-related attributes. This relates to underlying needs for social approval, personal expression and outer directed self-esteem were of least importance the respondents (Table 2). Solomon (1983) reiterated that consumers may value the prestige, exclusivity, or fashion ability of a brand because of how it relates to their self-concept. Non-product related attributes such as price which relating to the Tariff attribute was of moderate value to respondents (Table 2). This indicates significant percentages of the respondents were price sensitive and must be given the necessary attention when operators are rolling out services.

\subsection{Familiarity and usage of operator services}

As Marfo-Yiadom (2000) observes, consumers' preference for a brand in a product category and the evaluation of that brand relative to other known brands on a number of attributes can be influenced by the degree of familiarity with available brands in the product category. The results of respondents' familiarity with operator services are presented in Figure 6.

Insert Figure 6 - Here 
Short Media Messaging (SMS) (64\%) and Voice Calls (59\%) were the most familiar services identified by respondents with Caller Line Identification Presentation (CLIP) (7\%) the least familiar (Figure 7). This is consistent with our field observation that indicated that the CLIP was a privileged service available only for post-paid subscribers or subscribers on contract lines. Other services such as MMS, Free Night Calls were also identified by the respondents. The study further solicited past, current and future usage of operator services. The results are presented in Figures 7, 8 and 9 respectively.

\section{Insert Figure 7 - Here}

Voice Calls (49\%), SMS (44\%) and Ringtones (44\%) were the most used operator services by respondents in the past (Figure 7). The results again indicated usage was least among services such as Dual SIM IMSI and CLIP in the past. A measure of current usage also indicated a similar trend with familiarity to operator services. SMS, Voice Calls, Ringtones and Discounted Tariffs recorded highest usage (Figure 8). And this is consistent with the findings of Marfo-Yiadom (2000), who noted that 'the proportion of people who express a favourable attitude towards a brand is generally higher among its current users and lowest among those who have never used it all'.

Finally, as Figure 9 shows, a measure of future usage of operator services indicated that respondents' preference for Internet and Roaming services was more than any other. The results are again consistent with findings from online resource, Wikepedia, which asserts that since the mid-2000s, an increasing number of cellphones can connect to the Internet, a portion of which can navigated using cellphones (http://www.wikepedia.com/mobilephones). It continues that, in addition to the standard voice function of a telephone, current mobile phones may support many additional services and accessories such as SMS for text messaging, email, packet switching for access to the Internet and Multi Media Messaging (MMS) for sending and receiving photos and video.

Benady (2002), commenting on the shift from $2 \mathrm{G}$ to $3 \mathrm{G}$, explains that this shift is expected to change the way people use their mobile phones and the services operators offer. The rise of the $3 \mathrm{G}$ network and its consumer acceptance, he concludes, would be one of the toughest marketing challenges in recent history. Jones (2002), however, believes that $3 \mathrm{G}$ has the potential to be successful if it is marketed to the right audience with focus on real consumer needs.

\section{Insert Figure 8 \& Figure 9 - Here}

The study further sought to identify operator brands used by the respondents. The results showed that of the 100 respondents MTN, Tigo, Onetouch and Kasapa were used by 58\%, 28\%, 9\% and 3\% respectively of the target population (Figure 10). This is in line with, but slightly higher than, the ITU (2008) estimate of subscriber market share in the Ghanaian mobile industry, which credits MTN with 55\% market share.

\section{Insert Figure 10 - Here}

On satisfaction, $57 \%$ of the respondents indicated overall satisfaction with operator services (Figure 11). Although above-average satisfaction level was recorded, the rating was indicative of considerable dissatisfaction among respondents. The NCA recognizes this and reaffirms that, in spite of the challenges, management will constantly review, adapt or modify, develop and implement new rules or directives to keep Ghana abreast of global standards, within its fiscal and human capabilities (Mustapha, 2007).

\section{Insert Figure 11 - Here}

Furthermore, the study sought to understand the relationhip (if any) between the level of satifaction with operator brand use (Table 3). A crosstabulation of the two variables yielded that $44 \%$ of total satisfied respondents (57) were happy with Tigo's Services followed by MTN(37\%), Onetouch(12\%) and Kasapa (5\%).

\section{Insert Table 3 - Here}

Finally, on the relationship between operator brand use and respondents' intention to switch to alternative network, Tigo recorded the most probable alternative followed by Onetouch and Kasapa. Nineteen per cent of respondents indicated their intention to switch from the market leader MTN. In summary, Tigo,Onetouch, Kasapa and MTN respectively recorded 34\%,23\%,13\% and $11 \%$ as the next best alternative should respondents decide to switch from their current operators (Table 4).

\section{Conclusions and Recommendations}

The main objective of the study was to identify brand preference for mobile phone operator services in the Cape Coast metropolis of Ghana. The specific objectives were to identify user demography, information sources for mobile operator and services adoption, operator services usage characteristics and satisfaction levels among users in the Cape Coast metropolis.

The results revealed that dominant group of mobile phone users were under 40 years of age. This is a critical mass of the population in which industry players have to acknowledge in fashioning out services that meet this particular demography. Commercial sources were the most preferred source of information for respondents when choosing their mobile operator brand and services. Television was observed to be the most preferred channel by respondents. Friends, families and neighbours exert the least influence on respondents in choosing their operator brand. The choice of a mobile operator brand was more dependent on its key attribute of network coverage than any other attributes. There appeared to be no difference between familiarity with operator services and 
respondents' preference for operator services. Past and current usage of operator services however contrasted with future usage. The second mobile operator, Tigo, scored the highest satisfaction and most preferred alternative among respondents.

The findings of the study have implications for marketing policy. Young males, mainly students in the tertiary institutions, single and of Christian affiliations, dominated the demography. Since consumers vary on many dimensions, grouping them according to one or more characteristics such as demography is a way of breaking the clutter. Television, newspapers and friends are very important sources of information when it comes to choosing an operator brand or the services they offer. As such communicating brand 'touch points' using these media can achieve the desired response. Operators need to adopt the new paradigm in promotion mix termed Integrated Brand Communications. This is a holistic communications strategy that integrates all communications activities.

Furthermore, increased familiarity with operator service did not commensurate with current or future usage. This presents tremendous marketing communication opportunity to industry players to focus on brand 'touch points', eliciting a positive stimulus such as purchase and referrals. In an era of competition, and especially the rise of the mobile service industry, marketers need to conduct regular consumer surveys in order to find out how consumers rank their brand. Again, the evaluation of distinctive performance of a brand on selected attributes or characteristics in a product category will enable marketers take cognizance of the weakness in the brand offering and design marketing strategies for improvement.

Based on the conclusions drawn, a number of recommendations are made to assist practitioners and industry players in their service offering for the consumers: It is recommended that the critical mass that constitutes the target market and the brand position of a mobile operator should be clearly identified and communicated so as to fashion out services that meet their aspirations and needs. Operators need to adopt the new paradigm in promotion mix termed Integrated Brand Communications. This is a holistic communications strategy that integrates all communications activities such as public relations, advertising, investor relations, interactive or internal communications - to manage the Company's most precious asset - its brand. In connection with respondents' reasons for switching to competing brands being network and tariff related, further study in satisfaction among mobile service usage is recommended, to identify the immediate and remote causes behind low satisfaction levels among users. Lastly, it is recommended that brand communication becomes more assertive and consistent to create the needed synergies to induce a positive action and response.

It must be noted that the period of research was considered a limitation as it was not long enough to provide a comprehensive understanding of overall satisfaction. A small sample size of 100 customers was taken, so inferences cannot be drawn from the results. Future research should be undertaken on a periodic basis for developing a more accurate perspective on satisfaction with respective to the mobile operators, mobile handsets and the regulatory agency. This study was based on the prevailing customers' satisfaction. But the customers' satisfaction may change according to time, fashion, technology, development and so on.

\section{References}

Al-Hamad, R. (1993). Saudi citizens behaviour after purchasing in case of unsatisfaction. King Saud Journal, Managing Science, No. 5.

Al-Qahtani, S.M. (1991). Effectiveness of organizations concerned with the consumer protection in Saudi Arabia. An unpublished field study for a Master's Degree, College of Economy and Management-King Abdul Aziz University, Jeddah.

Asher, A. (1998). Going Global: A New Paradigm for Consumer Protection. The Journal of Consumer Affairs, Vol. 32 No. 2, pp 183-203. http://dx.doi.org/10.1111\%2Fj.1745-6606.1998.tb00406.x

Baker, M.J. (1991). Marketing: An introductory text. London: Macmillan.

Batra, R., and Ahtola, O.T. (1990). Measuring the Hedonic and Utilitarian Sources of Consumer Attitudes. Marketing Letters, 2 (2), 159-170. http://dx.doi.org/10.1007/BF00436035

Bedbury, S (2000). The Lawlor Review. Winter (December 29). 2000.66-67

Benady, D. (2002). As simple as one-two-3G. Marketing Week, 26-29.

Bhuian, S.N., Abdul-Muhmin, A.G., and Kim, D. (2001). Business Education and Its Influence on Attitudes to Business, Consumerism and Government in Saudi Arabia. Journal of Education for Business, Vol. 76 No. 4, pp 226-230. http://dx.doi.org/10.1080/08832320109601315

Blattberg, R. C., and Wisniewski, K.J. (1989). Price-Induced Patterns of Competition. Marketing Science. 8 (Fall), 29 1-309. http://dx.doi.org/10.1142/9789814287067_0008

Bockenholt, U., \& Dillion, W. R. (2000). Inferring Latent Brand Dependencies. Journal of Marketing Research. 37 (1): 72-87. http://dx.doi.org/10.1509/jmkr.37.1.72.18726

Bolton, R. (1998). A Dynamic Model of the Duration of the Customer's Relationship with a Continuous Service Provider: The Role of Satisfaction. Journal of Marketing Science, Vol 17 No. 1, 45-62. http://dx.doi.org/10.1287/mksc.17.1.45

Broadbent, K., \& Cooper, P. (1987). Research is Good for You. Marketing Intelligence \& Planning, 5: 3-9. http://dx.doi.org/10.1108/eb045740 
Business \& Financial Times. (2007). Mobile Phone Hits 7 Million Subscribers in Ghana. Newspaper article, (Dec 18) $1,7$.

Chernev, A. (2003). When More is Less and Less is More: The Role of Ideal Point Availability and Assortment in Consumer Choice. Journal of Consumer Research, 30 (2), 170-183. http://dx.doi.org/10.1086/376808

Chintagunta, P. K. (1999). Variety Seeking, Purchase Timing, and the "Lightning Bolt" Brand Choice Model. Marketing Science, 45 (4): 486-496. http://dx.doi.org/10.1287/mnsc.45.4.486

Davis, S (2002). Brand Asset Management: How Business Can Benefit from the Power of Brand. Journal of Consumer Marketing. 19 (4): 351-358.

Dhar, R., and Wertenbroch, K. (2000). Consumer Choice between Hedonic and Utilitarian Goods. Journal of Marketing Research, 37 (1), 60-71. http://dx.doi.org/10.1509/jmkr.37.1.60.18718

Dorsch, M.J., Grove, S.J., and Darden, W.R. (2000). Consumer Intentions to Use a Service Category. Journal of Services Marketing, 14 (2), 92-117. http://dx.doi.org/10.1108/08876040010309220

Enpocket. (2004). Enpocket Mobile Media Monitor (UK). Research Report, (February, 2004). 23-26.

Fitzsimons, G.J., Hutchinson, J.W., Williams, P., Alba, J.W., Chartrand, T.L., Huber, J., Kardes, F.R., Menon, G., Raghubir, P., Russo, J.E., Shiv, B., and Tavassoli, N.T. (2002). Non-Conscious Influences on Consumer Choice. Marketing Letters, 13 (3), 269-279. http://dx.doi.org/10.1023/A:1020313710388

Gerstheimer, O., and Lupp, C. (2004). Needs versus Technology: The Challenge to Design Third-Generation Mobile Application. Journal of Business Research, $57 \quad$ (12) December, 1409-1415. http://dx.doi.org/10.1016/S0148-2963(02)00430-7

Hansen, L. (2003). Service Layer Essential for Future Success. Ericsson Mobility World, General article. [Online] Available: http://www.ericsson.com/mobilityworld/sub/articles/other_articles/nl03jun (June)

Jones, S. (2002). 3G Launch Strategies, Early Adopters, Why \& How to Make Them Yours. Tarifica Report (October, 2002).42-45.

Karjaluoto, H., Karvonen, J., Pakola, J., Pietilä, M., Salo, J., and Svento, R. (2005). Exploring Consumer Motives in Mobile Phone Industry: An Investigation of Finnish Mobile Phone users. Proceedings of the 1st International Conference on Business Economics, Management, and Marketing (Athens, Greece). 3, 335-342.

Keller, K.L. (1993). Conceptualizing, Measuring, and Managing Customer-Based Brand Equity. Journal of Marketing, Vol. 57, No. 1. (Jan., 1993), 1-22. http://dx.doi.org/10.2307/1252054

Kim, H.S., and Yoon, C.H. (2004). Determinants of Subscriber Churn and Customer Loyalty in the Korean Mobile Telephony Market. Telecommunication Policy, Vol. 28 No. 9-10, pp. 751-765. http://dx.doi.org/10.1016/j.telpol.2004.05.013

Kotler, P. H. (1991). Marketing management: Analysis, planning, and control. (8th ed.). Englewood Cliffs, NJ: Prentice-Hall, Inc.

Kotler, P., and Keller, K. L. (2006). Marketing management, 12th ed. Englewood Cliffs, NJ: Prentice-Hall, Inc.

Kotler, P., Armstrong, G., Brown, L and Adam, S. (1998). Markerting. Sydney: Prentice-Hall.

Kumar, S. (2004). Mobile Communication: Global Trends in the 21st Century. International Journal of Mobile Communication, Vol.2, No.1, pp. 67-86. http://dx.doi.org/10.1504/IJMC.2004.004488

Lachance, M.J., and Nadia Choquette-Bernier. (2004). College Students' Consumer Competence: A Qualitative Exploration. International Journal of Consumer Studies, 28 (5), 433-442. http://dx.doi.org/10.1111/j.1470-6431.2004.00390.x

Laroche, M., Kim, C., and Matsui, T. (2003). Which Decision Heuristics are Used in Consideration Set Formation?. Journal of Consumer Marketing, 20 (3), 192-209. http://dx.doi.org/10.1108/07363760310472236

Lui, C.M. (2002). The Effects of Promotional Activities on Brand Decision in the Cellular Telephone Industry. The Journal of Product \& Brand Management, 11(1), 42-51. http://dx.doi.org/10.1108/10610420210419540

Marfo-Yiadom, E. (2000). Dynamics of Brand Preference: An Application of Expectancy-Value Model to Consumer Preference for Laundry Soap. Oguaa Social Science Journal, Vol. 2 No.1, June 2000 24-42.

Mason, C. H. (1990). New Product Entries and Product Class Demand. Marketing Science, March, pp. 58-73. http://dx.doi.org/10.1287/mksc.9.1.58

Mustapha, S. (2007). NCA's milestone: Communication Revolution and Transformation. ITU Paper, 262, 273-274.

Nijssen, E. J. (1999). Success Factors of Line Expansions of Fast-Moving Consumer Goods. European Journal Marketing, 33 (5/6): 450-469.

Papatla, P, Zahedi, F. M., \& Zekic-Susac, M. (2002). Leveraging the Strengths of Choice Models and Neural Networks: A Multiproduct Comparative Analysis. Decision Sciences, 33 (3): 433-468. http://dx.doi.org/10.1111/j.1540-5915.2002.tb01651.x

Park, C., Whan, B. J.J., and Deborah J. MacInnis. (1986). Strategic Brand Concept-Image Management. Journal of Marketing, 50 (October), 62: 1-35. http://dx.doi.org/10.2307/1251291 
Phillips, P. (1998). Buying a Brand: What You Can't See Can Hurt You. Design Management Journal (Winter): 43-46. http://dx.doi.org/10.1111/j.1948-7169.1998.tb00193.x

Plummer, J. T. (1985). How Personality Makes a Difference. Journal of Advertising Research, 24 (6), $27-31$.

Radhakrishna, G. (2007). Consumer Behaviour \& Marketing Planning: A Case Study of Mobile Communication System in Delhi State. PhD Thesis. Department of Commerce and Business Studies. Jamia Milia Islamic University. India.

Riquelme, H. (2001). Do Consumers Know What They Want? Journal of Consumer Marketing, 18(5), 437-448.

Roger, E. M. (1995). Diffusion of innovation, $4^{\text {th }}$ edition. New York: Free Press.

Sehovic, A. (2003). The Whole World in 3G: The Right Choice. GSMBOX, Ltd., Mobile News, Third Generation. [Online] Available: http://uk.gsmbox.com/news/mobile_news/all/95639.gsmbox

Solomon, M.R. (1983). The Role of Products as Social Stimuli: A Symbolic Interactionism Perspective. Journal of Consumer Research, 10 (December), 3 19-29. http://dx.doi.org/10.1086/208971

Srull, T.K. (1984). Methodological Techniques for the Study of Person Memory and Social Cognition. In Handbook of Social Cognition, Vol. 2, Robert S. Wyer and Thomas K. Srull, eds. Hillsdale, NJ: Lawrence Erlbaum Associates, 1-72.

Sugai, P. (2007). Exploring the Impact of Handset Upgrades on Mobile Content and Service Usage. International Journal of Mobile Communication, Vol. 5 No. $3, \quad 281-299$. http://dx.doi.org/10.1504/IJMC.2007.012395

Tornatzky, L. O \& Klien, K. J. (1982). Innovation Characteristics and Innovation Adoption-Implementation: A Meta-Analysis of Findings. IEEE Trans. On Eng. Management, 29 (1): 28-48.

VNU Marketing Information Services. (2003). Building Successful Brands. Insights Asia Pacific. Issue 100: 1 Wagstaff, J. (2002). SMS: Keep It Plain and Pithy. Far Eastern Review, 165(37): 40-41.

Ward, K. (2004). Marketing finance: Turning marketing strategies into shareholder value. Elsevier: Butterworth-Heienemann.

Wilska, T.A. (2003). Mobile Phone Use as Part of Young People's Consumption Styles. Journal of Consumer Policy, Vol. 26 No. 4, 441-463. http://dx.doi.org/10.1023/A:1026331016172

Table 1. Demographic Characteristics of Respondents

\begin{tabular}{|l|l|l|}
\hline Characteristics & Frequency & Percent \\
\hline Age & & \\
Under 20 years & 8 & 8 \\
21-30 years & 60 & 60 \\
31-40 years & 19 & 19 \\
41-50 years & 6 & 6 \\
$51-60$ years & 7 & 7 \\
\hline Sex & & \\
Male & 71 & 71 \\
Female & 29 & 29 \\
\hline Level of Education & & \\
Primary & 1 & 1 \\
Secondary/Technical & 19 & 19 \\
Tertiary & 72 & 72 \\
Professional & 8 & 8 \\
\hline Occupation & & \\
Student & 45 & 45 \\
Blue-Collar & 14 & 14 \\
White-Collar & 30 & 30 \\
Other & 11 & 11 \\
\hline
\end{tabular}


Table 2. Ranking of Mobile Operator Attributes in Cape Coast Metropolis

\begin{tabular}{|l|l|l|l|}
\hline Attribute & Frequency & Per cent & Rank \\
\hline Network Coverage & 83 & $19 \%$ & 1 \\
Customer Service & 60 & $14 \%$ & 2 \\
Access to Recharge Credit & 60 & $14 \%$ & 2 \\
Tariff & 53 & $12 \%$ & 3 \\
Value-Added Services & 52 & $12 \%$ & 4 \\
Brand Image & 46 & $10 \%$ & 5 \\
Brand Communication & 43 & $10 \%$ & 6 \\
Activation \& Operating Cost & 43 & $10 \%$ & 6 \\
\hline Total & 440 & $100 \%$ & \\
\hline
\end{tabular}

Table 3. Crosstabulation of Mobile Operator Brand Use and Satisfaction Level with Operator Services

\begin{tabular}{|l|l|l|l|l|l|l|}
\hline & & \multicolumn{3}{|l|}{ Satisfaction Level with Operator Services } & Total \\
\hline \multirow{5}{*}{$\begin{array}{l}\text { Mobile } \\
\text { Operator }\end{array}$} & $\begin{array}{l}\text { No } \\
\text { Response }\end{array}$ & Yes & No & $\begin{array}{l}\text { Do Not } \\
\text { Know }\end{array}$ & $\begin{array}{l}\text { No } \\
\text { Response } \\
\text { Brand Use }\end{array}$ \\
& Response & & 1 & 1 & 0 & 2 \\
& & & & & \\
& MTN & 3 & 21 & 25 & 9 & 58 \\
& Tigo & 1 & 25 & 2 & 0 & 28 \\
& Onetouch & 0 & 7 & 1 & 1 & 9 \\
& Kasapa & 0 & 3 & 0 & 0 & 3 \\
\hline Total & & 4 & 57 & 29 & 10 & 100 \\
\hline
\end{tabular}

Table 4. Crosstabulation of Mobile Operator Brand Use and Respondents Choice of Alternative Operator Brand

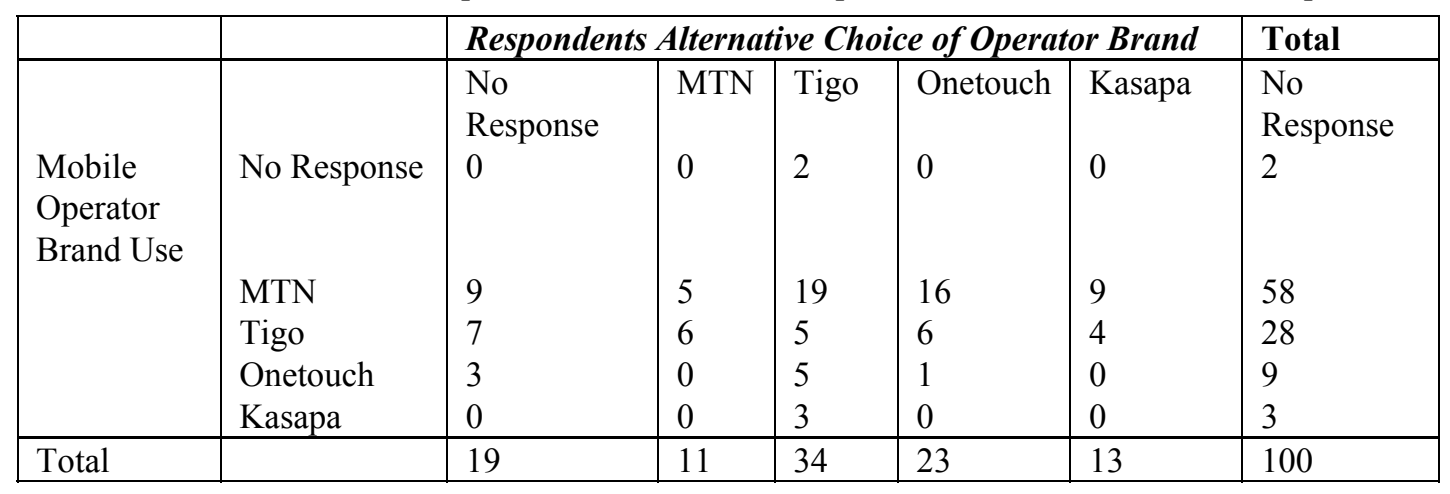

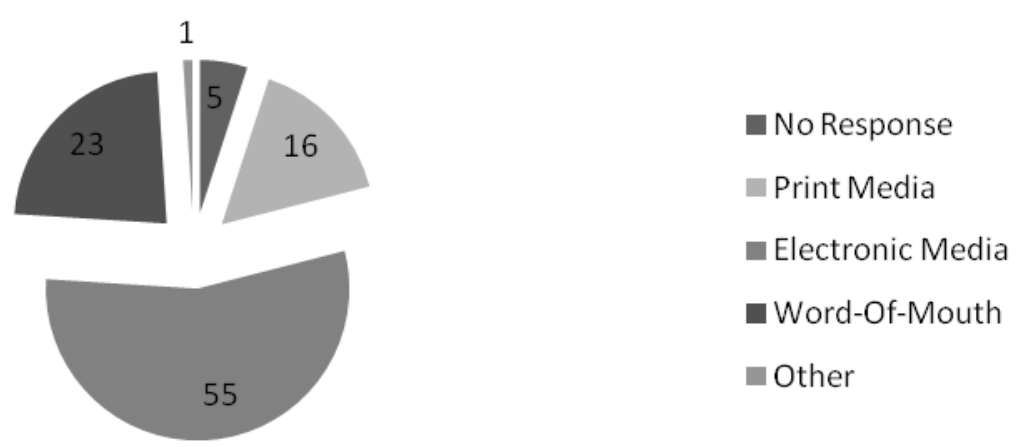

Figure 1. Sources of Information for Operator Brand Choice 


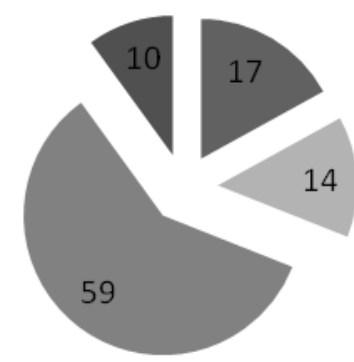

$$
\begin{aligned}
& \text { No Response } \\
& \text { Print Media } \\
& \text { Electronic Media } \\
& \text { Word-Of-Mouth }
\end{aligned}
$$

Figure 2. Sources of Information for the Adoption of Mobile Operator Services

\section{Most Prefered Print Source for Adoption of Operator Services}

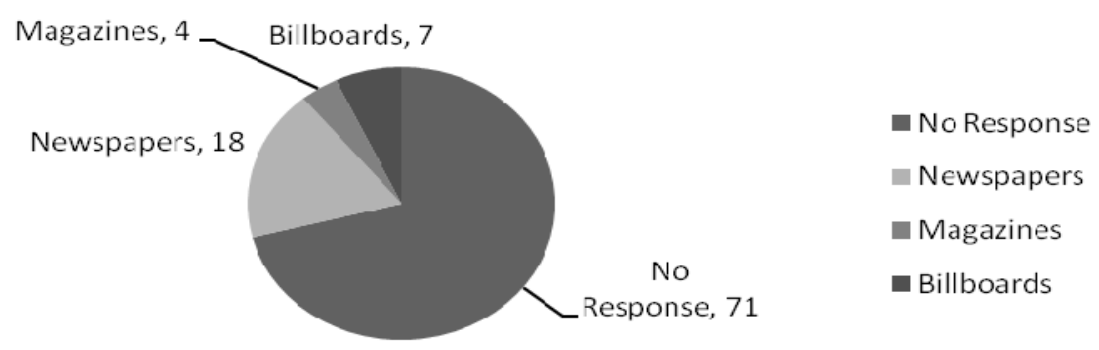

Figure 3. Most Important Print Source of Information in Adopting Operator Services among Respondents

\section{Most Prefered Word-Of-Mouth Source for Adoption Operator Services}

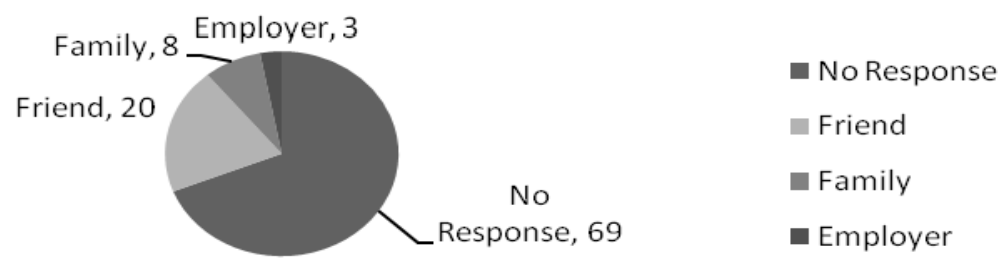

Figure 4. Most Important Word-of-Mouth Source of Information in Adopting Operator Services among Respondents

Most Prefered Electronic Source for Adoption of Operator Services

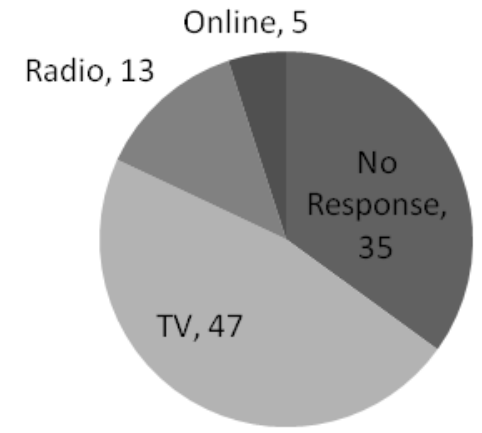

$$
\begin{aligned}
& \text { No Response } \\
& \text { TV } \\
& \text { Radio } \\
& \text { Online }
\end{aligned}
$$

Figure 5. Most Important Electronic Source of Information in Adopting Operator Services among Respondents 


\section{Respondents Familiarity with operator services}

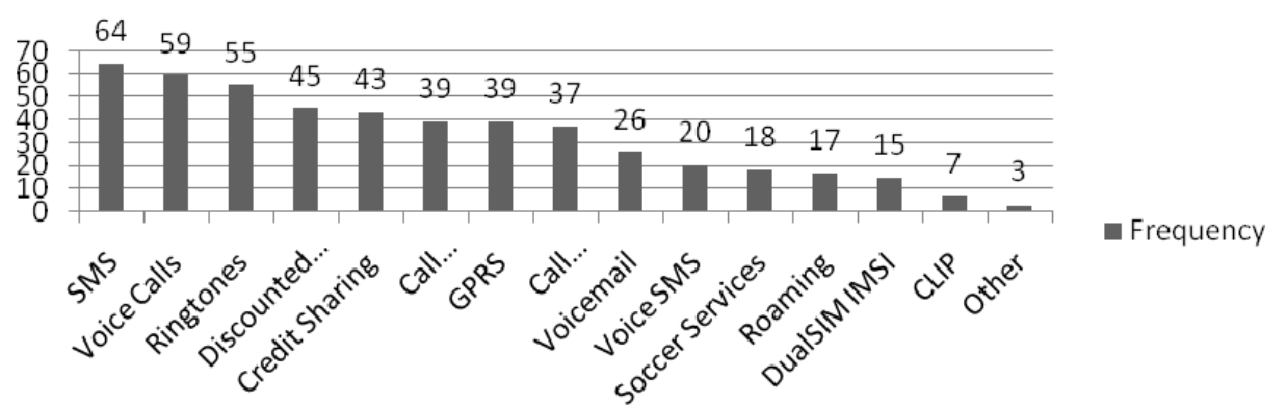

Figure 6. Respondents Familiarity with Operator Services

Past Usage of Operator Services by Respondents
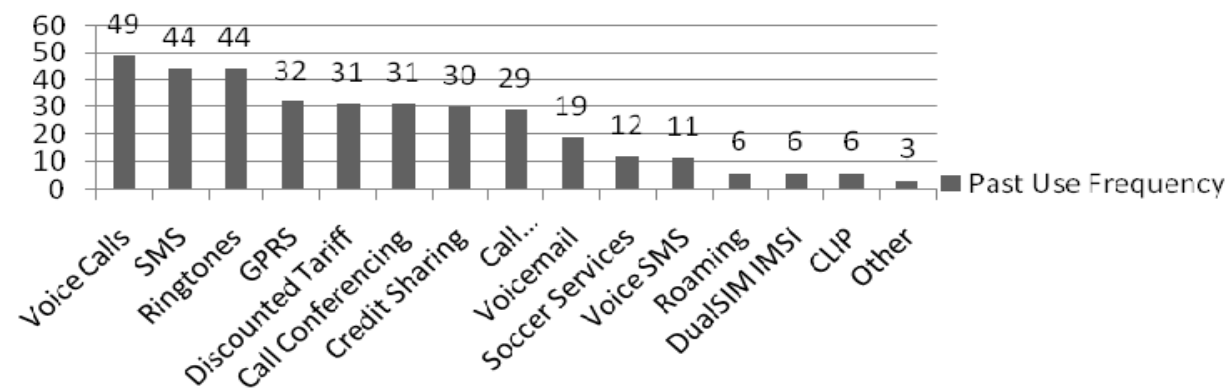

Figure 7. Past Usage of Operator Services by Respondents

\section{Current Usage of Operator Services by Respondents}

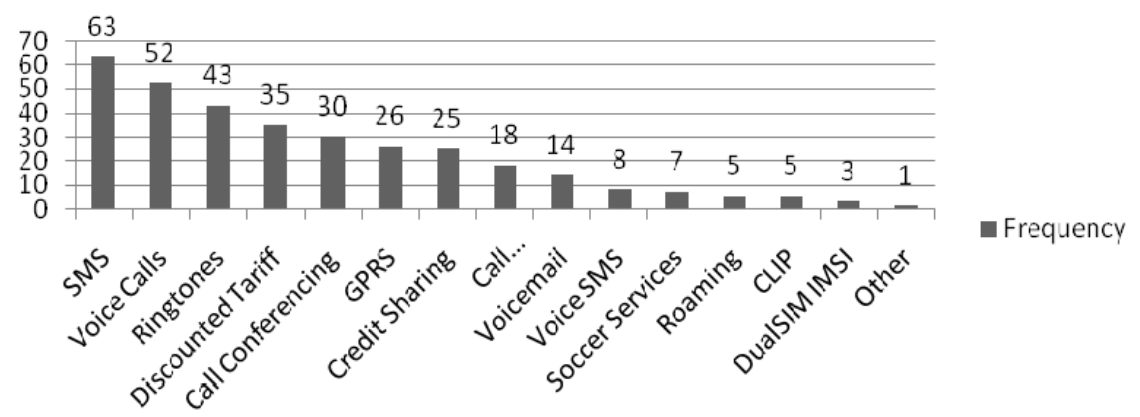

Figure 8. Current Usage of Operator Services by Respondents 


\section{Future Use of Operator Services by Respondents}

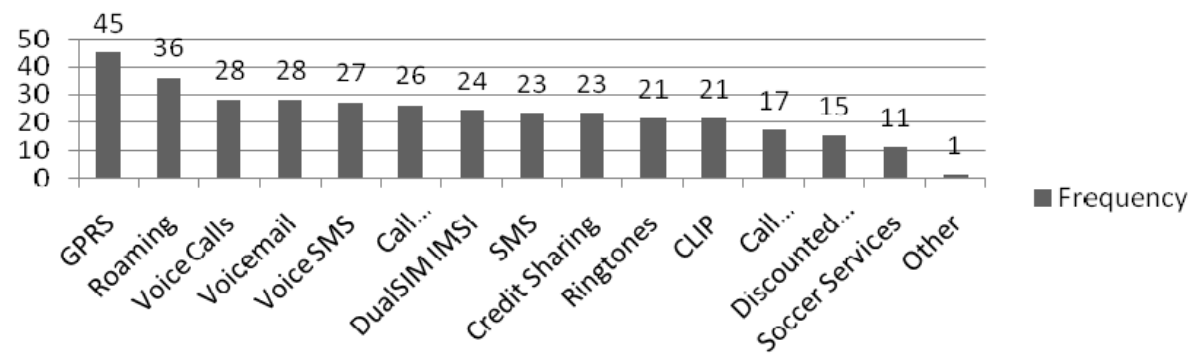

Figure 9. Future usage of Operator Services by Repondents

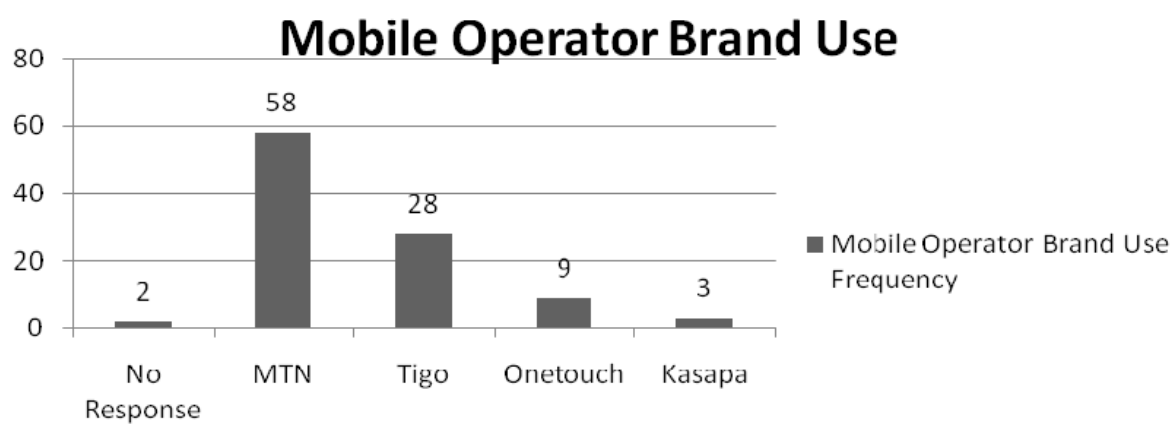

Figure 10. Operator Brand Use among Respondents

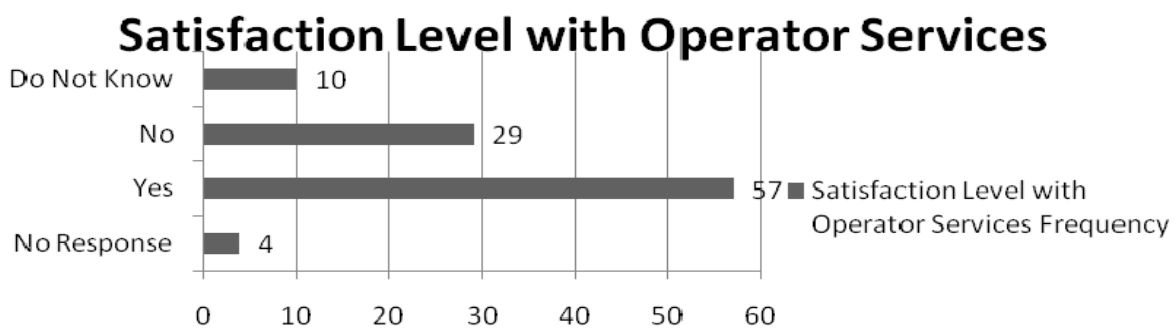

Figure 11. Respondents Satisfaction with Operator Services Source 